\section{Exposure to intimate partner violence and malnutrition among young adult Bangladeshi women: cross-sectional study of a nationally representative sample}

\author{
Exposição à violência entre parceiros íntimos \\ e desnutrição entre mulheres jovens de \\ Bangladesh: um estudo transversal de uma \\ amostra nacional representativa
}

Exposición a la violencia doméstica y malnutrición entre mujeres adultas jóvenes bangladesíes: estudio transversal de una muestra representativa nacionalmente
Jannatul Ferdos 1

Md. Mosfequr Rahman 1

doi: 10.1590/0102-311X00113916

Correspondence

Md. M. Rahman

Department of Population Science and Human Resource

Development, University of Rajshahi.

Rajshahi / Northern - CEP 6205 - Bangladesh.

mosfeque@gmail.com

1 University of Rajshahi, Rajshahi, Bangladesh. 


\section{Introduction}

Malnutrition, both undernutrition/underweight and overnutrition/overweight, remains a pervasive and damaging condition in under developed and developing countries. Undernutrition is the leading risk factor for mortality in the world, contributing to nearly 3.5 million deaths 1 and $16 \%$ of all disability-adjusted life years (DALYs) lost globally 2. It is also an important determinant of maternal and child death 3. In Bangladesh, 24\% of ever married women aged 15-49 years are undernourished (body mass index $-\mathrm{BMI}<18.5 \mathrm{~kg} / \mathrm{m}^{2}$ ) and women in the age group 15-19 years are more likely to be thin or undernourished than other age cohorts 4 . Even among the wealthiest quintile of society, $8.4 \%$ of women are underweight 4 . Undernutrition in Bangladesh continues to be a serious public health problem.

Overnutrition or obesity have significant health and economic consequences and are associated with an increased risk of developing various non-communicable diseases (NCDs), including hypertension, coronary heart disease, diabetes, stroke and some types of cancer ${ }^{5}$. Although overnutrition in Bangladesh is still not a major problem, the prevalence of overweight women is increasing. The proportion of women who are overweight or obese $\left(\mathrm{BMI} \geq 25 \mathrm{~kg} / \mathrm{m}^{2}\right)$ has increased from $2.7 \%$ in 1996-1997 to $10.1 \%$ in 2007 , and $16.5 \%$ in 20116 . Therefore, it is evidently important to determine the prevalence of overnutrition as well as its consequences on woman's health along with measuring the consequences of undernutrition, particularly in developing countries.

The literature on the relationship between being underweight or overweight/obese and experience of intimate partner violence (IPV) is limited. IPV is considered one of the main psychosocial factors that might influence women's nutritional status 7. IPV increases psychological stress among women, which, in turn, increases oxidative stress 8 and metabolic level 9 , risk factors for undernutrition. IPV against women can provoke an eating disorder, unhealthy weight control practices and poorer treatment outcomes for the disorders 10 , as well as chronic fatigue, physical inactivity, and disabilities preventing work and daily activities 11. Some recent studies in Bangladesh 12 and India 13 indicate the association between IPV and undernutrition among reproductive-aged women. However, a study in Egypt found a significant relationship between the IPV experience and obesity in adulthood 14 . These studies have examined only the relationship between the experiences of IPV and undernutrition/obesity in different settings. A research conducted in Bangladesh indicates that young women experience more IPV than their older counterparts ${ }^{15}$. This study, therefore, assessed the association between being underweight or overweight/obese and the experience of IPV among young adult women aged 15-24 years in Bangladesh.

\section{Methods}

\section{Sample}

This cross-sectional study used data from the 2007 Bangladesh Demographic Health Survey (BDHS), conducted by the National Institute of Population Research and Training of the Ministry of Health and Family Welfare of Bangladesh, from March to August 2007 16. The survey used a sample drawn from the total population of Bangladesh residing in private dwellings. A stratified, multistage cluster sample of 361 primary sampling units was conducted, 227 in rural areas and 134 in urban areas. A total of 11,178 eligible women aged 15-49 years were identified to participate in the survey; 10,996 were interviewed, a response rate of $98.4 \%$. Data collection procedures for the BDHS were approved by the ORC Macro Institutional Review Board. Details of data collection and management procedures are described elsewhere 16 . In our analyses, we included only currently married young adult women aged 15-24 years $(\mathrm{N}=1,086)$, who were not pregnant at the time of the survey.

\section{Measures}

The BMI, calculated as weight in kilograms divided by height in meters squared, was used to assess undernutrition and overnutrition in this study. BMI is chosen to assess underweight and overweight 
mothers because it does not require a reference table from a well-nourished population. To fulfill the requirement of this study, variable was created to define the categories underweight, normal and overweight $/$ obese for BMI $<18.5 \mathrm{~kg} / \mathrm{m}^{2}$, between 18.5 to $24.99 \mathrm{~kg} / \mathrm{m}^{2}$, and $\geq 25 \mathrm{~kg} / \mathrm{m}^{2}$, respectively 17 .

Women's experience of IPV was the main exposure of interest in this study. The survey measured IPV with a shortened and modified Conflict Tactics Scale (CTS) 18. Each married woman was asked "(Has) your (last) husband ever done any of these things to you: (i) pushed you, shaken you, or throwed something at you; (ii) slapped you; (iii) twisted your arm or pulled your hair; (iv) punched you with his fist or with something that could hurt you; (v) kicked you, dragged you, or beaten you up; (vi) tried to choke you or burnt you on purpose; (vii) threatened or attacked you with a knife, gun, or any other weapon; (viii) physically forced you to have sexual intercourse with him even when you did not want to?" A positive answer to any of these questions [(i)-(vii)] indicated physical perpetration and a positive answer to question (viii) indicated sexual IPV perpetration. Again, questions [(i)-(iv)] indicate experience of minor physical violence and questions [(v)-(vii)] indicate experience of severe physical violence.

Several socioeconomic and demographic variables were included in the analysis as potential confounding factors, which were associated with the experience of IPV in previous studies 12,13,19,20. Age at marriage was categorized as being married before 18 years vs. 18 years or older. The women's educational level was classified as: no education (0 year), primary (1-5 years), secondary or higher (6 years or more). Place of residence was categorized as rural vs. urban. The wealth variable categorized respondents into quintiles according to the household's score on the DHS wealth index, which is based on the household's amenities, assets and living conditions 21 . The sample was then divided into quintiles with $1=$ poorest and $5=$ wealthiest, $20 \%$ of household. Total numbers of household members were classified as $(2-4,5-6$ or $\geq 7)$. Maternal working status was created as classifying women according to whether they were working at the time of the survey or not. Maternal height was categorized into two categories: $<145$ or $\geq 145 \mathrm{~cm}$.

\section{Statistical analysis}

Descriptive statistics were used to describe the distribution variables of interest. Descriptive data were presented as standard deviations means for continuous variables, and frequencies and percentages for categorical variables. Chi-square tests were used to investigate associations between IPV and sociodemographic variables. Multivariate logistic regression was performed to examine the relationship between undernutrition and overnutrition/obesity and maternal experience of IPV. The multicollinearity of the variables was verified by examining the variance inflation factors; in all cases, the values were lower than 2.0, indicating that multicollinearity was low. In all the analyses, the level of significance was p-value $<0.05$. All statistical analyses were conducted using IBM SPSS 20.0 for Windows (IBM Corp., Armonk, USA) to accommodate the complex sampling design of BDHS.

\section{Ethical considerations}

The 2007 BDHS follows a standard protocol and was given complete approval by the ORC Macro Institutional Review Board. The protocol of the survey was also reviewed and approved by the National Ethics Committee of the Bangladesh Ministry of Health and Family Welfare. Informed consent was obtained from each respondent for this survey. This study was exempt from full review as it was based on secondary use of anonymous data set with no identifiable information on the survey participants.

\section{Results}

The mean age of the respondents was $20 \pm 2.54$ (mean $\pm \mathrm{SD}$ ), $83.7 \%$ were married before reaching their 18th birthday, $89.9 \%$ had less than two children, $64.6 \%$ were from the rural background, $15.2 \%$ had no education, and $76.1 \%$ were not working (Table 1). From the total sample of young adult women, $61.2 \%$ had normal weight (BMI 18.50-24.99), 32.6\% were underweight (BMI < 18.50) and 
Table 1

Sociodemographic, nutritional and intimate partner violence (IPV) characteristics of married Bangladeshi women aged 15-24 years. Bangladesh Demographic Health Survey (BDHS), 2007 ( $N=1,086)$.

\begin{tabular}{|c|c|c|}
\hline Characteristics & $\mathbf{n}$ & $\%(95 \% \mathrm{Cl})$ \\
\hline Mean age & 1,086 & $20.0 \pm 2.54($ mean $\pm S D)$ \\
\hline \multicolumn{3}{|l|}{ Age at marriage (years) } \\
\hline$<18$ & 909 & $83.7(81.4-85.7)$ \\
\hline$\geq 18$ & 177 & $16.3(14.2-16.3)$ \\
\hline \multicolumn{3}{|c|}{ Number of household members } \\
\hline $2-4$ & 557 & $51.3(48.3-54.3)$ \\
\hline $5-6$ & 268 & $24.7(22.2-27.3)$ \\
\hline$\geq 7$ & 260 & $24.0(21.5-26.6)$ \\
\hline Data missing & 1 & \\
\hline \multicolumn{3}{|l|}{ Children ever born } \\
\hline$<2$ & 976 & $89.9(87.9-91.5)$ \\
\hline$\geq 2$ & 110 & $10.1(8.4-12.0)$ \\
\hline \multicolumn{3}{|l|}{ Place of residence } \\
\hline Rural & 702 & $64.6(61.7-67.4)$ \\
\hline Urban & 384 & $35.4(32.5-38.2)$ \\
\hline \multicolumn{3}{|l|}{ Wealth quintile } \\
\hline Lowest & 190 & $17.5(15.3-19.8)$ \\
\hline Second & 227 & $20.9(18.6-23.4)$ \\
\hline Middle & 218 & $20.1(17.8-22.5)$ \\
\hline Fourth & 225 & $20.7(18.4-23.2)$ \\
\hline Highest & 226 & $20.8(18.5-23.3)$ \\
\hline \multicolumn{3}{|l|}{ Respondents' education } \\
\hline No education & 165 & $15.2(13.1-17.4)$ \\
\hline Primary & 352 & $32.4(29.7-35.2)$ \\
\hline Secondary and higher & 569 & $52.4(49.4-55.3)$ \\
\hline \multicolumn{3}{|l|}{ Currently working } \\
\hline No & 826 & $76.1(73.4-78.5)$ \\
\hline Yes & 260 & $23.9(21.5-26.5)$ \\
\hline \multicolumn{3}{|c|}{ Ever used modern contraceptives } \\
\hline No & 256 & $23.6(21.1-16.1)$ \\
\hline Yes & 830 & $76.4(73.8-78.8)$ \\
\hline Mean BMI & 1,086 & $20.0 \pm 2.9($ mean $\pm S D)$ \\
\hline \multicolumn{3}{|l|}{ Respondents' BMI } \\
\hline Underweight & 354 & $32.6(29.8-35.4)$ \\
\hline Normal & 665 & $61.2(58.3-64.0)$ \\
\hline Overweight/Obese & 67 & $6.2(4.9-7.7)$ \\
\hline \multicolumn{3}{|l|}{ Respondents' height (cm) } \\
\hline$<145$ & 180 & $16.6(14.4-18.9)$ \\
\hline$\geq 145$ & 906 & $83.4(81.1-85.5)$ \\
\hline \multicolumn{3}{|l|}{ Physical and/or sexual IPV } \\
\hline No & 713 & $65.7(62.8-68.4)$ \\
\hline Yes & 372 & $34.3(31.5-37.1)$ \\
\hline Data missing & 1 & \\
\hline \multicolumn{3}{|l|}{ Physical IPV only } \\
\hline No & 770 & $71.0(68.4-73.6)$ \\
\hline Yes & 315 & $29.0(26.4-31.8)$ \\
\hline Data missing & 1 & \\
\hline
\end{tabular}


Table 1 (continued)

\begin{tabular}{lcc}
\hline Characteristics & $\mathbf{n}$ & \% (95\%Cl) \\
\hline $\begin{array}{l}\text { Sexual IPV only } \\
\text { No }\end{array}$ & 928 & $85.5(83.2-87.4)$ \\
$\quad$ Yes & 158 & $14.5(12.5-16.7)$ \\
Minor physical IPV & & \\
$\quad$ No & 587 & $54.1(51.0-57.0)$ \\
Yes & 499 & $45.9(43.0-48.9)$ \\
Severe physical IPV & & \\
$\quad$ No & 938 & $86.4(84.2-88.2)$ \\
Yes & 148 & $13.6(11.7-15.8)$ \\
\hline
\end{tabular}

95\%Cl: 95\% confidence interval; BMI: body mass index; SD: standard deviation.

$6.2 \%$ were overweight/obese (BMI $\geq 25)$. Approximately one-third (34.3\%) of the young adult women reported they had experienced physical and/or sexual violence from their husbands in the 12 months preceding the survey: 29\% reported physical violence only in the absence of sexual violence, $14.4 \%$ reported sexual violence only in the absence of physical violence (Table 1).

The bivariate analyses revealed several significant differences in the experience of IPV across various sociodemographic groups (Table 2). Age at marriage was significantly associated with all forms of IPV. Higher percentages of women who were married before 18 years of age experienced significantly more physical IPV, physical and/or sexual IPV, minor physical IPV, and severe physical IPV. Women whose height fell below the cutoff of $145 \mathrm{~cm}$ were also more likely to report physical IPV, sexual IPV, physical and/or sexual IPV and severe physical IPV. Physical IPV, physical and/or sexual IPV, minor physical IPV and severe physical IPV were significantly associated with the BMI of women. A higher percentage of underweight women reported experiencing IPV than the normal and overweight/obese category (Table 2).

Results from multivariate analyses indicated that undernutrition or overnutrition/obesity was associated with all the forms of IPV (Table 3). Underweight $(\mathrm{BMI}<18.50)$ women were 1.39 times, 1.48 times, 1.31 times, and 2.11 times more likely to report the experience of physical IPV, physical and/or sexual IPV, minor physical IPV, and severe physical IPV, respectively, than normal weight range women (BMI 18.5-24.99). However, overweight/obese (BMI $\geq 25.00)$ women were significantly more likely to report physical IPV (OR = 1.45; 95\%CI: 1.12-2.88), sexual IPV (OR = 1.29; 95\%CI: 1.023.24), physical and sexual IPV (OR = 1.51; 95\%CI: 1.09-2.88), minor physical IPV (OR = 1.24; 95\%CI: 1.01-2.26), and severe physical IPV (OR $=2.39$; 95\%CI: $1.35-7.19)$ than normal weight range women. Moreover, results also indicated that women who married at 18 years old or later, were member of the highest wealth quintile, and had secondary or higher education were significantly less likely to experience violence from husbands. Urban residents reported to experience more physical IPV $(\mathrm{OR}=1.53$; 95\%CI: 1.09-2.13), physical and/or sexual IPV (OR = 1.38; 95\%CI: 1.08-1.98), minor physical IPV (OR = 1.81; 95\%CI: 1.31-2.50), and severe physical IPV (OR = 1.89; 95\%CI: 1.24-2.88) than rural residents (Table 3 ).

\section{Discussion}

This article presents the association between being both under-and overweight and experience of IPV among young adult Bangladeshi women aged 15-24 years. Our study findings indicate that one-third of young adult women are suffering from chronic undernutrition and $6.2 \%$ of women are overweight or obese. Young Bangladeshi women are more likely to be underweight than older women but less likely to be overweight/obese 4,6,16. These findings suggest that both underweight and overweight/ obese women coexist and accounted for two-fifths among young adult Bangladeshi women. The fact that this population is often at the bottom of the food chain, with little or no decision-making power 
Table 2

Descriptive statistics of young adult Bangladeshi women aged 15-24 years, by different form of intimate partner violence (IPV) experienced. Bang/adesh Demographic Health Survey (BDHS), 2007 ( $N=1,086)$.

\begin{tabular}{|c|c|c|c|c|c|}
\hline Characteristics & $\begin{array}{c}\text { Physical IPV only } \\
\%(95 \% \mathrm{Cl})\end{array}$ & $\begin{array}{l}\text { Sexual IPV only } \\
\%(95 \% \mathrm{Cl})\end{array}$ & $\begin{array}{c}\text { Physical and/or } \\
\text { sexual IPV\% }(95 \% \mathrm{Cl})\end{array}$ & $\begin{array}{c}\text { Minor physical IPV } \\
\%(95 \% \mathrm{Cl})\end{array}$ & $\begin{array}{c}\text { Severe physical IPV } \\
\%(95 \% \mathrm{CI})\end{array}$ \\
\hline \multicolumn{6}{|l|}{ Age at marriage (years) } \\
\hline$<18$ & $31.3(28.3-34.3)$ & $15.0(12.8-17.4)$ & $36.2(33.1-39.4)$ & $49.6(46.3-52.8)$ & $15.0(12.8-17.4)$ \\
\hline$\geq 18$ & $17.5(12.6-23.7)$ & $12.4(8.3-18.1)$ & $24.3(18.5-31.1)$ & $27.1(21.1-34.1)$ & $6.8(3.9-11.4)$ \\
\hline $\mathrm{p}$-value & $<0.001$ & 0.382 & 0.002 & $<0.001$ & 0.004 \\
\hline \multicolumn{6}{|l|}{$\begin{array}{l}\text { Number of household } \\
\text { members }\end{array}$} \\
\hline $2-4$ & $34.9(31.0-38.9)$ & $14.7(12.0-17.9)$ & $39.2(37.0-45.1)$ & $52.8(48.6-56.9)$ & $17.6(14.6-20.9)$ \\
\hline $5-6$ & $25.7(20.8-31.3)$ & $14.6(10.8-19.2)$ & $30.6(25.4-36.3)$ & $44.0(38.2-50.0)$ & $11.9(8.6-16.3)$ \\
\hline$\geq 7$ & $19.6(15.2-24.8)$ & $14.2(10.5-19.0)$ & $27.3(22.2-33.0)$ & $33.1(27.6-39.0)$ & $6.9(4.4-10.6)$ \\
\hline $\mathrm{p}$-value & $<0.001$ & 0.983 & 0.001 & $<0.001$ & $<0.001$ \\
\hline \multicolumn{6}{|l|}{ Children ever born } \\
\hline$<2$ & $28.3(25.5-31.1)$ & $14.4(12.3-16.8)$ & $33.7(30.8-36.7)$ & $44.2(41.0-47.3)$ & $12.8(10.8-15.0)$ \\
\hline$\geq 2$ & $35.8(27.4-45.1)$ & $15.5(9.8-23.6)$ & $39.4(30.7-48.8)$ & $61.8(52.5-70.3)$ & $20.9(14.3-29.4)$ \\
\hline $\mathrm{p}$-value & 0.102 & 0.776 & 0.231 & $<0.001$ & 0.019 \\
\hline \multicolumn{6}{|l|}{ Place of residence } \\
\hline Rural & $28.5(25.2-31.9)$ & $15.4(12.9-18.2)$ & $34.6(31.2-38.2)$ & $45.0(41.3-48.7)$ & $12.3(10.0-14.8)$ \\
\hline Urban & $30.0(31.4-41.9)$ & $13.0(10.0-16.7)$ & $33.7(29.1-38.5)$ & $47.7(42.7-52.6)$ & $16.1(12.8-20.1)$ \\
\hline $\mathrm{p}$-value & 0.594 & 0.291 & 0.757 & 0.404 & 0.074 \\
\hline \multicolumn{6}{|l|}{ Wealth quintile } \\
\hline Lowest & $32.6(26.3-39.5)$ & $21.6(16.3-27.9)$ & $41.1(34.3-48.1)$ & $53.2(46.0-60.1)$ & $15.3(10.8-21.0)$ \\
\hline Second & $34.8(28.9-41.2)$ & $16.7(12.4-22.1)$ & $40.5(34.3-47.0)$ & $52.9(46.3-59.2)$ & $16.3(12.0-21.6)$ \\
\hline Middle & $33.0(27.1-39.5)$ & $12.4(8.6-17.4)$ & $35.8(29.7-42.3)$ & $52.8(46.1-59.2)$ & $16.1(11.7-21.5)$ \\
\hline Fourth & $27.2(21.8-33.4)$ & $12.4(8.7-17.4)$ & $31.7(25.9-3.0)$ & $42.2(35.9-48.7)$ & $14.2(10.2-19.4)$ \\
\hline Highest & $18.1(13.6-23.6)$ & $10.6(7.2-15.3)$ & $23.5(18.4-29.4)$ & $30.1(24.4-36.3)$ & $6.6(4.0-10.6)$ \\
\hline$p$-value & 0.001 & 0.012 & $<0.001$ & $<0.001$ & 0.015 \\
\hline \multicolumn{6}{|l|}{ Respondents' education } \\
\hline No education & $39.4(32.2-47.0)$ & $16.4(11.5-22.7)$ & $44.2(36.8-51.8)$ & $56.4(48.3-63.7)$ & $24.2(18.3-31.3)$ \\
\hline Primary & $32.8(28.0-37.8)$ & $17.3(13.7-21.6)$ & $37.6(32.7-42.8)$ & $53.1(47.9-58.2)$ & $16.8(13.2-21.0)$ \\
\hline Secondary and & $23.7(20.4-27.4)$ & $12.3(9.8-15.2)$ & $29.3(25.7-33.2)$ & $38.5(34.5-42.5)$ & $8.6(6.5-11.2)$ \\
\hline \multicolumn{6}{|l|}{ higher } \\
\hline $\mathrm{p}$-value & $<0.001$ & 0.085 & 0.001 & $<0.001$ & $<0.001$ \\
\hline \multicolumn{6}{|l|}{ Currently working } \\
\hline No & $28.2(25.2-31.4)$ & $13.4(11.2-15.9)$ & $32.5(29.3-35.7)$ & $43.8(40.8-47.2)$ & $11.7(9.7-14.1)$ \\
\hline Yes & $31.5(26.2-37.4)$ & $18.1(13.8-23.2)$ & $40.0(34.2-46.0)$ & $52.7(46.6-58.6)$ & $19.6(15.2-24.8)$ \\
\hline $\mathrm{p}$-value & 0.307 & 0.039 & 0.026 & 0.012 & 0.001 \\
\hline \multicolumn{6}{|l|}{ Ever use modern } \\
\hline \multicolumn{6}{|l|}{ contraceptives } \\
\hline No & $20.7(16.2-26.0)$ & $12.9(9.3-17.5)$ & $25.8(20.8-31.4)$ & $31.6(26.2-37.5)$ & $11.7(8.3-16.2)$ \\
\hline Yes & $31.6(28.5-34.8)$ & $15.1(12.8-17.6)$ & $36.9(33.7-40.2)$ & $50.4(46.9-53.7)$ & $14.2(12.0-16.7)$ \\
\hline $\mathrm{p}$-value & 0.001 & 0.389 & 0.001 & $<0.001$ & 0.308 \\
\hline \multicolumn{6}{|l|}{ Respondents' height } \\
\hline \multicolumn{6}{|l|}{$(\mathrm{cm})$} \\
\hline$<145$ & $35.6(28.9-42.7)$ & $22.8(17.2-29.4)$ & $43.3(36.3-50.6)$ & $52.2(44.9-53.4)$ & $18.9(13.8-25.2)$ \\
\hline$\geq 145$ & $27.7(24.9-30.7)$ & $12.9(10.8-15.2)$ & $32.5(29.5-35.6)$ & $44.7(41.5-47.9)$ & $12.6(10.5-14.9)$ \\
\hline $\mathrm{p}$-value & 0.035 & 0.001 & 0.005 & 0.064 & 0.024 \\
\hline \multicolumn{6}{|l|}{ Respondents' BMI } \\
\hline Underweight & $31.6(27.0-36.6)$ & $15.0(11.6-19.0)$ & $37.0(32.1-42.1)$ & $48.3(43.1-53.5)$ & $16.1(12.6-20.3)$ \\
\hline Normal & $28.6(25.3-32.1)$ & $14.9(12.4-17.8)$ & $34.0(30.5-37.7)$ & $45.9(42.1-49.7)$ & $13.1(10.7-15.8)$ \\
\hline Overweight/Obese & $19.4(11.7-30.4)$ & $9.0(4.1-18.2)$ & $22.4(14.0-33.7)$ & $34.3(24.1-46.2)$ & $6.0(2.3-14.3)$ \\
\hline p-value & 0.009 & 0.407 & 0.028 & 0.048 & 0.039 \\
\hline
\end{tabular}

95\% Cl: 95\% confidence interval; BMI: body mass index. 
Table 3

Adjusted odds ratios (OR) from multivariate logistic regression analyses examining the association between maternal body mass index (BMI) and maternal experience of intimate partner violence (IPV).

\begin{tabular}{|c|c|c|c|c|c|}
\hline \multirow[t]{2}{*}{ Characteristics } & \multirow{2}{*}{$\begin{array}{c}\text { Physical IPV only } \\
\text { OR }(95 \% \mathrm{CI})\end{array}$} & \multirow{2}{*}{$\begin{array}{l}\text { Sexual IPV only } \\
\text { OR }(95 \% \mathrm{Cl})\end{array}$} & \multirow{2}{*}{$\begin{array}{c}\text { Physical and/or } \\
\text { sexual IPV } \\
\text { OR }(95 \% \mathrm{CI})\end{array}$} & \multirow{2}{*}{$\begin{array}{c}\text { Minor physical IPV } \\
\text { OR }(95 \% \mathrm{Cl})\end{array}$} & \multirow{2}{*}{$\begin{array}{c}\text { Severe physical IPV } \\
\text { OR }(95 \% \mathrm{Cl})\end{array}$} \\
\hline & & & & & \\
\hline \multicolumn{6}{|l|}{ Respondents' BMI } \\
\hline Normal & 1.00 & 1.00 & 1.00 & 1.00 & 1.00 \\
\hline Underweight & $1.39 *(1.09-2.71)$ & $1.41(0.58-3.43)$ & $1.48 * *(1.12-2.75)$ & $1.31 *(1.03-2.11)$ & $2.11 *(1.40-6.19)$ \\
\hline Overweight/Obese & $1.45 * *(1.12-2.88)$ & $1.29 *(1.02-3.24)$ & $1.51 * *(1.09-2.88)$ & $1.24 * \star(1.01-2.26)$ & $2.39 * \star(1.35-7.19)$ \\
\hline \multicolumn{6}{|l|}{ Age at marriage } \\
\hline$<18$ & 1.00 & 1.00 & 1.00 & 1.00 & 1.00 \\
\hline$\geq 18$ & $0.59 *(0.37-0.91)$ & $0.56 * *(0.41-0.92)$ & $0.65 * *(0.42-0.89)$ & $0.51 * *(0.34-0.74)$ & $0.61 *(0.39-0.98$ \\
\hline \multicolumn{6}{|l|}{$\begin{array}{l}\text { Number of household } \\
\text { members }\end{array}$} \\
\hline $2-4$ & 1.00 & 1.00 & 1.00 & 1.00 & 1.00 \\
\hline $5-6$ & $1.93 * * *(1.33-2.78)$ & 0.89 (0.57-1.39) & $1.48 *(1.06-2.07)$ & $1.92 * \star *(1.39-2.65)$ & $2.46 * *(1.42-4.26)$ \\
\hline$\geq 7$ & $1.19(0.78-1.82)$ & $0.92(0.56-1.52)$ & $1.01(0.68-1.47)$ & $1.27(0.87-1.85)$ & $1.36(0.73-2.56)$ \\
\hline \multicolumn{6}{|l|}{ Children ever born } \\
\hline$<2$ & 1.00 & 1.00 & 1.00 & 1.00 & 1.00 \\
\hline$\geq 2$ & $1.29(0.81-2.03)$ & $0.96(0.53-1.73)$ & $1.18(0.75-1.84)$ & 1.76 * $(1.35-2.75)$ & $1.62(0.93-2.83)$ \\
\hline \multicolumn{6}{|l|}{ Place of residence } \\
\hline Rural & 1.00 & 1.00 & 1.00 & 1.00 & 1.00 \\
\hline Urban & $1.53 *(1.09-2.13)$ & $0.98(0.64-1.51)$ & 1.38 * $(1.08-1.98)$ & $1.81 * \star \star(1.31-2.50)$ & $1.89 * *(1.24-2.88)$ \\
\hline \multicolumn{6}{|l|}{ Wealth quintile } \\
\hline Lowest & 1.00 & 1.00 & 1.00 & 1.00 & 1.00 \\
\hline Second & $1.08(0.71-1.65)$ & $0.77(0.47-1.27)$ & $1.10(0.67-1.49)$ & $0.94(0.83-1.40)$ & $1.09(0.63-1.89)$ \\
\hline Middle & $1.04(0.73-1.50)$ & $0.62(0.38-1.01)$ & $0.86(0.61-1.22)$ & $1.09(0.77-1.53)$ & $1.15(0.71-1.85)$ \\
\hline Fourth & $0.84(0.58-1.22)$ & $0.74(0.45-1.20)$ & $0.80(0.56-1.14)$ & $0.71(0.50-1.01)$ & 1.09 (0.67-1.77) \\
\hline Highest & $0.45 * *(0.29-0.71)$ & $0.71 *(0.57-0.98)$ & $0.53 * *(0.35-0.81)$ & $0.37 * \star *(0.25-0.56)$ & $0.42 * *(0.22-0.80)$ \\
\hline \multicolumn{6}{|l|}{$\begin{array}{l}\text { Respondents' } \\
\text { education }\end{array}$} \\
\hline No education & 1.00 & 1.00 & 1.00 & 1.00 & 1.00 \\
\hline Primary & 0.77 * $(0.52-0.96)$ & $1.12(0.67-1.58)$ & $0.79 *(0.54-0.92)$ & $0.65 * *(0.42-0.87)$ & $0.64 * *(0.40 .0 .96)$ \\
\hline \multicolumn{6}{|l|}{ higher } \\
\hline \multicolumn{6}{|l|}{ Currently working } \\
\hline No & 1.00 & 1.00 & 1.00 & 1.00 & 1.00 \\
\hline Yes & $0.97(0.71-1.33)$ & $1.35(0.92-1.98)$ & $1.21(0.91-1.63)$ & $1.16(0.86-1.56)$ & $1.52 *(1.03-2.25)$ \\
\hline \multicolumn{6}{|l|}{$\begin{array}{l}\text { Respondents' height } \\
(\mathrm{cm})\end{array}$} \\
\hline$<145$ & 1.00 & 1.00 & 1.00 & 1.00 & 1.00 \\
\hline$\geq 145$ & $0.76(0.53-1.08)$ & $0.52 * *(0.35-0.79)$ & $0.67 *(0.48-0.94)$ & $0.81(0.57-1.14)$ & $0.73(0.47-1.15)$ \\
\hline
\end{tabular}

95\%Cl: 95\% confidence interval.

$* \mathrm{p}<0.05$;

** $\mathrm{p}<0.01$;

$\star \star \star ~ p<0.001$.

about food distribution in the household, could lead to food security issues and may contribute to their poor nutritional status. Moreover, women aged 15-24 years need adequate nutrients to support fast physical, mental and emotional growth. The unawareness of their own health and nutritional status could be another reason associated with their poor nutritional status. A study from South-Asia showed that the prevalence of overweight-obesity among women of reproductive age has risen between 1996 and 2006 and overweight-obesity was positively related to age 22 . This study also found that 29\% and $14.5 \%$ of young 
adult women experienced physical and sexual violence, respectively. These findings are similar to the earlier findings of experiencing IPV among women between 15-49 years in Bangladesh 16, including young adults 15 . Comparing with the earlier study 15, the likelihood of experiencing IPV decreases with age, which suggests that as women grow older, their roles as mothers become more prominent than their roles as wives, and they achieve a certain status at the household and community levels 23 .

The results from nationally representative data set provide evidence for a relation between malnutrition and IPV experience among young adult Bangladeshi women. Underweight woman experienced more physical and physical and/or sexual IPV than a normal weight range woman. In this South-Asian region, the withholding of food is a documented form of abuse that is likely correlated with the perpetration of physical violence 24 . This withholding of food through psychological or emotional abuse resulted in insufficient intake of diet among these populations and could mediate the relation between physical IPV and nutrient deficiencies that may cause undernutrition. Furthermore, IPV is strongly associated with a woman's inability to make decisions for herself and her family, including the choice of types and quantities of food that a woman prepares as she cares for herself and her children 25. This might also explain how IPV reflects the nutritional status among these women.

Another explanation underpinning the association between IPV and undernutrition is that the relation between IPV and nutritional deficiencies may also involve a mediating effect of psychological stress. A study in South-Asia documented that women who experience IPV tend to have higher levels of psychological stress 26, which could also be related to underweight status. Psychological stress increases oxidative stress 8 , a term used to describe a number of chemical reactions that produce free radicals and other organic molecules capable of damaging living tissue, risk factors for undernutrition. However, chronic stress also increases metabolic rate and energy expenditure 9,27, a process that could cause weight loss in a person with a fixed and limited caloric intake. That psychological stress may be associated with undernutrition in a low-income country is consistent with the result of a longitudinal study from the United Kingdom, which found that, under stressful conditions, lean subjects tend to lose weight 28 .

Our findings also indicated that overweight/obese women experienced significantly more IPV (all the forms of IPV) than normal range women. Experience of sexual IPV is significantly associated with overweight/obese women, which corroborates the findings of the study of Egypt ${ }^{14}$. Thus, Bangladeshi young adult women who experience sexual IPV may experience adverse psychological after-effects, which leads to excess energy intake or a more sedentary lifestyle, and ultimately to a higher chance of being obese. Most research in food-rich environments in industrialized nations has documented a link between chronic stress and obesity mediated by metabolic changes 29 or behavioral adjustments 30 that promote abdominal adipose tissue deposition. Findings from a longitudinal study in the United Kingdom indicated that, under stressful conditions, overweight subjects tend to gain weight 28. Thus, young adult Bangladeshi women, who are on the verge of the normal nutritional range (BMI $\geq 23.0$ and $<25.0$ ), may gain weight due to stressful conditions in the family after experiencing sexual IPV and enter the overweight nutritional status.

Although our findings indicate important insights into the nutritional status and its association with IPV in Bangladesh, the results should be interpreted in the light of several limitations. First, the findings rely on self-reported data and retrospective accounts, which are vulnerable to recall bias and desirability bias. The second limitation is that a single item of sexual IPV precludes a more thorough documentation of marital sexual abuse; use of multiple behaviorally specific questions about the type or types of sexual abuse inflicted could have elicited a greater number of reports of sexual IPV 31. Third, the BDHS is a cross-sectional observational survey, which prevents us from inferring that domestic violence causes malnutrition among these women. Indeed, the causal pathway may be reversed, with violence being a husband's reaction against his malnourished wife. Longitudinal designs that can address causality or cross-sectional path or mediational models using exposure to IPV and outcome variables will be more relevant than mere correlational designs. Fourth, as there is a strong psychological element used in this study, it will be more informative to shine some light on these women's feelings. However, BDHS survey did not evaluate the participating subjects for mood symptoms or negative moods, such as depression or stress. Finally, the sample of this study is limited to young adult Bangladeshi women and should not be generalized to women of other age groups and other countries, though the association found in this study is consistent with those of the few studies of this type. 
Despite these potential limitations, our findings reveal a significant relationship between IPV and malnutrition among young adult Bangladeshi women. The findings strongly suggest that malnutrition in such settings may partly have its roots in the subordination of women. Future longitudinal studies are needed to investigate the influence of potential mechanisms mediating the relationship between IPV and undernutrition and overnutrition among these populations.

\section{Contributors}

J. Ferdos originated the study design, data analysis, and writing. Md. M. Rahman contributed to study design, statistical analysis, data interpretation, and provided critical revisions of the article.

\section{Acknowledgments}

The authors thank MEASURE DHS for the permission to use data from the 2007 Bangladesh DHS.

\section{References}

1. Black RE, Allen LH, Bhutta ZA, Caulfield LE, de Onis M, Ezzati M, et al. Maternal and child undernutrition: global and regional exposures and health consequences. Lancet 2008; 371:243-60.

2. Murray CJ, Lopez AD. Global mortality, disability, and the contribution of risk factors: Global Burden of Disease Study. Lancet 1997; 349:1436-42.

3. Caulfield LE, de Onis M, Blössner M, Black RE. Undernutrition as an underlying cause of child deaths associated with diarrhea, pneumonia, malaria, and measles. Am J Clin Nutr 2004; 80:193-8.

4. National Institute of Population Research and Training; Mitra and Associates; ICF International. Bangladesh Demographic and Health Survey 2011. Dhaka: National Institute of Population Research and Training; Mitra and Associates/Calverton: ICF International; 2013.

5. Eckel RH, York DA, Rössner S, Hubbard V, Caterson I, St Jeor ST, et al. Prevention Conference VII: obesity, a worldwide epidemic related to heart disease and stroke: executive summary. Circulation 2004; 110:2968-75.

6. Khan SH, Talukder SH. Nutrition transition in Bangladesh: is the country ready for this double burden. Obes Rev 2013; 14 Suppl 2:126-33.

7. World Health Organization. World report on violence. Geneva: World Health Organization; 1997.

8. Sivonova M, Zitnanova I, Hlincikova L, Škodácek I, Trebaticka J, Ďuracková Z. Oxidative stress in university students during examinations. Stress 2004; 7:183-8. 
9. Seematter G, Guenat E, Schneiter P, Cayeux C, Jequier E, Tappy L. Effects of mental stress on insulin-mediated glucose metabolism and energy expenditure in lean and obese women. Am J Physiol Endocrinol Metab 2000; 279:E799-805.

10. Rodríguez M, Pérez V, García Y. Impact of traumatic experiences and violent acts upon response to treatment of a sample of Colombian women with eating disorders. Int J Eat Disord 2005; 37:299-306.

11. Ellsberg M, Jansen HA, Heise L, Watts $\mathrm{CH}$, Garcia-Moreno C. Intimate partner violence and women's physical and mental health in the WHO multi-country study on women's health and domestic violence: an observational study. Lancet 2008; 371:1165-72.

12. Rahman M, Nakamura K, Seino K, Kizuki M. Intimate partner violence and chronic undernutrition among married Bangladeshi women of reproductive age: are the poor uniquely disadvantaged? Eur J Clin Nutr 2013; 67:301-7.

13. Ackerson LK, Subramanian S. Domestic violence and chronic malnutrition among women and children in India. Am J Epidemiol 2008; 167:1188-96.

14. Yount KM, Li L. Domestic violence and obesity in Egyptian women. J Biosoc Sci 2011; 43:85-99.

15. Rahman M, Hoque MA, Makinoda S. Intimate partner violence against women: is women empowerment a reducing factor? A study from a national Bangladeshi sample. J Fam Violence 2011; 26:411-20.

16. National Institute of Population Research and Training; Mitra and Associates; Macro International. Bangladesh Demographic and Health Survey 2007. Dhaka: National Institute of Population Research and Training; Mitra and Associates/Calverton: Macro International; 2009.

17. WHO Expert Consultation. Appropriate bodymass index for Asian populations and its implications for policy and intervention strategies. Lancet 2004; 363:157-63.

18. Straus MA. Measuring intrafamily conflict and violence. The conflict tactic scales. In: Straus MA, Gelles RJ, editors. Physical violence in American families: risk factors and adaptations to violence in 8145 families. New Brunswick: Transaction Publishers; 1990. p. 29-47.

19. Madhivanan P, Krupp K, Reingold A. Correlates of intimate partner physical violence among young reproductive age women in Mysore, India. Asia Pac J Public Health 2014; 26:169-81.
20. Rahman M, Hoque MA, Mostofa MG, Makinoda S. Association between adolescent marriage and intimate partner violence a study of young adult women in Bangladesh. Asia Pac J Public Health 2014; 26:160-8.

21. Rutstein SO, Johnson K. The DHS wealth index. Calverton: ORC Macro; 2004. (DHS Comparative Reports, 6).

22. Balarajan Y, Villamor E. Nationally representative surveys show recent increases in the prevalence of overweight and obesity among women of reproductive age in Bangladesh, $\mathrm{Ne}$ pal, and India. J Nutr 2009; 139:2139-44.

23. Kishor S, Johnson K. Profiling domestic violence: a multi-country study. Calverton: MEASURE DHS+/ORC Macro; 2004.

24. Raj A, Livramento KN, Santana MC, Gupta J, Silverman JG. Victims of intimate partner violence more likely to report abuse from in-laws. Violence Against Women 2006; 12:936-49.

25. Sethuraman K, Lansdown R, Sullivan K. Women's empowerment and domestic violence: the role of sociocultural determinants in maternal and child undernutrition in tribal and rural communities in South India. Food Nutr Bull 2006; 27:128-43.

26. Kumar S, Jeyaseelan L, Suresh S, Ahuja RC. Domestic violence and its mental health correlates in Indian women. Br J Psychiatry 2005; 187:62-7.

27. Seywert AJ, Tappy L, Gremion G, Giusti V. Effect of a program of moderate physical activity on mental stress-induced increase in energy expenditure in obese women. Diabetes Metab 2002; 28:178-83.

28. Kivimäki M, Head J, Ferrie J, Shipley MJ, Brunner E, Vahtera J, et al. Work stress, weight gain and weight loss: evidence for bidirectional effects of job strain on body mass index in the Whitehall II study. Int J Obes (Lond) 2006; 30:982-7.

29. Kyrou I, Chrousos GP, Tsigos C. Stress, visceral obesity, and metabolic complications. Ann N Y Acad Sci 2006; 1083:77-110.

30. Dallman MF, Pecoraro NC, la Fleur SE. Chronic stress and comfort foods: self-medication and abdominal obesity. Brain Behav Immun 2005; 19:275-80.

31. Ellsberg M, Heise L, Peña R, Agurto $S$, Winkvist A. Researching domestic violence against women: methodological and ethical considerations. Stud Fam Plann 2001; 32:1-16. 


\section{Resumo}

$O$ estudo explora as relações entre desnutrição e violência entre parceiros intimos (VPI) em uma amostra de 1.086 mulheres adultas jovens (15-24 anos) de Bangladesh, usando dados transversais do Bangladesh Demographic Health Survey (BDHS) de 2007. Cerca de um terço $(33,4 \%)$ dessas mulheres relataram terem sofrido VPI fisica e/ou sexual, 14,5\% apenas VPI sexual e 29\% apenas VPI física praticada pelo marido. Cerca de 32,6\% das mulheres adultas jovens eram desnutridas (IMC $<18,5)$, enquanto 6,2\% apresentavam sobrepeso (IMC $\geq 25)$. As mulheres com baixo peso sofriam mais VPI física $(O R=1,39$; IC95\%: 1,09-2,71) e VPI física elou sexual $(O R=1,48$; IC95\%: 1,12-2,75) quando comparadas às mulheres eutróficas. Os resultados também indicam uma associação positiva entre sobrepeso/obesidade e todas as formas de VPI. Os achados indicam que a exposição à VPI tem um papel significativo na experiência das adultas jovens de baixo peso e com sobrepeso/obesidade e confirmam que são necessários programas e politicas nutricionais e de saúde para as mulheres jovens de Bangladesh.

Violência por Parceiro Íntimo; Desnutrição; Peso Corporal; Índice de Massa Corporal

\section{Resumen}

Este estudio explora la relación entre la malnutrición y violencia doméstica (IPV por sus siglas en inglés) entre 1.086 mujeres adultas jóvenes bangladesíes, con una edad entre 15-24 años, usando datos de un estudio transversal, procedentes del 2007 Bangladesh Demographic Health Survey (BDHS). Cerca de un tercio $(33,4 \%)$ de las mujeres adultas jóvenes sufrieron violencia física $y / o$ sexual IPV, 14,5\% sufrieron sólo sexual IPV, y un $29 \%$ sufrieron sólo física IPV por parte de sus maridos. Cerca de un 32,6\% de las mujeres adultas jóvenes se encontraban por debajo del peso ideal $(I M C<18,5)$ y un 6,2\% tenían sobrepeso (BMI $\geq$ 25). Las mujeres con el peso por debajo del apropiado sufrían más violencia física IPV $(O R=1,39$; IC95\%: 1,09-2,71) y física y/o sexual IPV $(O R=$ 1,48; IC95\%: 1,12-2,75), en comparación con el rango normal de mujeres. Los resultados también indican una asociación positiva entre sufrir sobrepeso/obesidad y todas las formas de IPV. Los hallazgos del estudio indican que sufrir IPV tiene un papel significativo en el peso por debajo del peso ideal y con sobrepeso/obesas de las mujeres adultas jóvenes y el apoyo a salud de estas mujeres más jóvenes, que necesitan tanto programas de nutrición, como politicas especialmente dirigidas a mujeres que sufren violencia doméstica.

Violencia de Pareja; Desnutrición; Peso Corporal; Índice de Masa Corporal
Submitted on 30/Jun/2016

Final version resubmitted on 28/Nov/2017

Approved on 02/Feb/2018 